\title{
JARINGAN SYARAF TIRUAN UNTUK MEMPREDIKSI NILAI SISWA SMA MENGGUNAKAN BACKPROPAGATION
}

\author{
Evan Hikler Damanik*1, Eka Irawan ${ }^{2}$, Fitri Rizki ${ }^{3}$, \\ ${ }^{1,2,3}$ Sekolah Tinggi Ilmu Komputer Stikom Tunas Bangsa \\ Jl. Sudirman, Proklamasi, Siantar Barat., Kota Pematang Siantar, Sumatera Utara \\ E-mail : *puteralangit007@gmail.com
}

\begin{abstract}
ABSTRAK- Penguasaan seorang siswa/i terhadap sebuah mata pelajaran sangat mempengaruhi pemberian nilai yang dilakukan oleh pengajar yang bersangkutan. Perlunya pengajar atau guru memantau setiap nilai dari siswa/i yang diajarkan ilmu pengetahuan pada bidangnya masing-masing. Dengan perkembangan teknologi yang sangat cepat, sangat membantu pengajar dalam mengetahui atau memprediksi nilai yang akan didapatkan siswa/i terkait. Penelitian ini bertujuan untuk menerapkan kinerja jaringan syaraf tiruan algoritma backpropagation dalam memprediksi nilai siswa/i sekolah menengah atas dengan berbagai model dan meminimalkan error nya. Pada penelitian ini penulis menggunakan data nilai siswa/i sekolah menengah atas negeri 1 sidamanik. Dalam pengolahan data nilai, penulis menggunakan jaringan syaraf tiruan dengan algoritma backpropagation sebagai langkah-langkah logis untuk melakukan prediksi nilai ujian nasional siswa/i sekolah menengah atas. Pokok permasalahan pada penelitian ini adalah terjadinya penurunan nilai ujian nasional siswa/i dibeberapa mata pelajaran, yang kedepannya siswa/i akan mengalamin kesulitan dalam mencapai universitas atau sekolah tinggi yang diinginkan. Disimpulkan bahwa dalam memprediksi jaringan syaraf tiruan mampu menghasilkan akurasi yang cukup akurat pada hasil pengolahan data testing. Learning Rate sangat mempengaruhi kecepatan hasil iterasi maupun tingkat akurasi yang dihasilkan. Penelitian ini menghasilkan arsitektur terbaik yakni 3-12-1 pada pengolahan data nilai bahasa Indonesia dengan tingkat akurasi 95\%.Untuk penelitian selanjutnya perlu adanya percepatan dan optimasi dalam melakukan proses prediksi serta pengaplikasian algoritma backpropagation dengan algoritma jaringan syaraf tiruan lain agar menghasilkan optimasi yang lebih baik dan stabil.
\end{abstract}

Kata kunci : Nilai Siswa/i, Sekolah, JST, Backpropagation

\section{PENDAHULUAN}

Pengenalan Pola masa lampau pada jaringan syaraf tiruan merupakan cara yang dilakukan untuk memprediksi kejadian di masa mendatang dengan data-data valid dan integritas datanya bisa dipertanggung jawabkan. Memprediksi akan membantu memperbaiki keadaan menjadi lebih baik dan lebih terukur dalam melanjutkan kehidupan. Perkembangan teknologi yang pesat sangat membantu dalam melakukan prediksi, serta mempermudah dalam melakukan penelitian yang berkaitan pemrosesan data yang cepat dan tepat.

Guru merupakan orang tua pengganti ketika berada di sekolah dasar sampai sekolah menengah atas. Proses mengajar seorang guru sangat menentukan nilai dari siswa yang diajarnya, baik dalam memberikan materi maupun nasehat-nasehat yang membangun daya pikir siswa. Institusi berkualitas akan menyediakan fasilitas lengkap untuk menunjang belajar siswa agar mendapatkan nilai yang memenuhi standar.

Kebutuhan akan nilai yang mencapai standar sehingga siswa harus bekerja keras untuk mencapainya. Sistem penilaian dan pelaksanaan kurikulum yang tepat dan akurat akan membantu siswa untuk menghindari terjadinya kemerosotan nilai dan frustasi yang akan dialami oleh seorang siswa. "Konvensional merupakan sistem seleksi konsep awal suatu metode untuk memprediksi nilai siswa dengan menggunakan bantuan software maupun hardware komputer yang didukung melalui pendekatan jaringan syaraf tiruan dan algoritma backpropagation.

Penulis melakukan penelitian di sekolah SMA N 1 Sidamanik dengan penggunaan data nilai pada semester 1 sampai dengan semester 4. Data yang diperoleh oleh penulis menampilkan bahwa terjadinya penurunan nilai di beberapa mata pelajaran.

Jaringan syaraf tiruan merupakan salah satu cabang ilmu yang mempelajari bagaimana kinerja syaraf otak manusia yang diubah ke dalam bentuk komputasi dengan menggunakan input sebagai data masukan berupa informasi awal yang akan diolah dengan pola, Hidden Layer sebagai data tersembunyi yang langsung diamati atau disebut data sedang diolah, Output sebagai data keluaran yang akan menghasilkan sebuah informasi yakni solusi dari permasalahan tersebut.

Beberapa Paper yang berkaitan dengan penelitian penulis adalah dilakukan oleh [1] berjudul Aplikasi Jaringan Saraf Tiruan Backpropagation Untuk Memprediksi Prestasi Siswa SMA (Studi Kasus: Prediksi Prestasi Siswa SMAN 4 Ambon) menghasilkan Menunjukkan bahwa korelasi antara NEM dam total nilai siswa semester 1 kelas X cukup baik dengan error yang kecil [2] berjudul "Analisis Algoritma Backpropagation Dengan SVM Dalam Hasil Prediksi Nilai Ujian Nasional Pada Sekolah Tingkat Pertama" dengan hasil pengujian antara backpropagation dan algoritma SVM menghasilkan nilai MSE terendah yaitu backpropagation dengan 
MSE rata-rata 103,3. Struktur atau pola yang digunakan untuk pengujian algoritma backpropagation dengan 7 node input layer, 5 node hidden layer dan 1 node output layer, sedangkan jika menggunakan struktur algoritma backpropagation dengan 7 node input layer, 7 node hidden layer dan 1 node output layer MSE adalah 106,6. Nilai rararata MSE pada algoritma SVM adalah 200.

Berdasarkan kesimpulan dari judul diatas penulis mengambil judul skripsi "Jaringan Syaraf Tiruan Untuk Memprediksi Nilai Siswa SMA Menggunakan Backpropagation Dengan Metode Inisialisasi Bobot Awal"

\section{ISI PENELITIAN}

Penelitian harus menghasilkan output atau keluaran sebagai bentuk kesimpulan atau hipotesis awal untuk melaksanakan sebuah penelitian/riset terdadap suatu data. Berikut adalah output dari riset skripsi yang dihasilkan :

\subsection{Normalisasi Data}

Dalam penelitian ini normalisasi data sangat diperlukan, dikarenakan pemrosesan data akan menjadi lebih mudah dengan diubah kedalam bentuk desimal sehingga ketika diolah tidak menghasilkan data keluaran yang banyak dengan ukuran besar. Berikut persamaan yang digunakan untuk normalisasi data:

$\mathrm{x}=\frac{0.8(x-a)}{b-a}+0.1$

Penjelasan :

X' : Data Transformasi

$\mathrm{X} \quad$ : Data Normalisasi

a : Data Jumlah Minimum

b : Data Jumlah maksismum

Pembagian data dibagi menjadi dua yakni data pelatihan (training) dan data pengujian (testing). Untuk perhitungan pada data normalisasi dapat dilihat pada tabel 2.1 dan 2.2 :

Tabel 2.1. Data Training Sebelum di Normalisasi

\begin{tabular}{|c|l|c|c|c|c|}
\hline \multicolumn{5}{|c|}{ TRAINING } \\
\hline NO & \multicolumn{1}{|c|}{ Nama Siswa } & X1 & X2 & X3 & Target \\
\hline 1 & Ade Pramita Damanik & 93 & 80 & 86 & 86 \\
\hline 2 & Adlan Fadila & 71 & 75 & 70 & 82 \\
\hline 3 & Afriani Damanik & 60 & 72 & 89 & 85 \\
\hline 4 & Afry Wulan Sihaloho & 58 & 66 & 65 & 75 \\
\hline 5 & Agnes Marshinta Tambun & 79 & 82 & 81 & 82 \\
\hline 6 & Agung Martahan Sigiro & 58 & 68 & 67 & 75 \\
\hline 7 & Aisyah Fadhilah Nasution & 59 & 70 & 80 & 81 \\
\hline 8 & Andreas Natanael Purba & 56 & 65 & 64 & 67 \\
\hline 9 & Angga Antonius Silalahi & 58 & 66 & 71 & 74 \\
\hline
\end{tabular}

\begin{tabular}{|c|l|c|c|c|c|}
10 & Anggi Apriani & 78 & 89 & 90 & 91 \\
\hline 11 & Anggi Setiawan Simanjuntak & 57 & 68 & 65 & 80 \\
\hline 12 & Anggraini Darmayanti & 56 & 70 & 75 & 82 \\
\hline 13 & Anisa Putri Ardila & 75 & 85 & 82 & 82 \\
\hline 14 & Anugrah Debora Sibarani & 84 & 89 & 90 & 93 \\
\hline 15 & Aprilah Yuswani & 68 & 74 & 76 & 84 \\
\hline 16 & Armelita Kristianty Harahap & 74 & 78 & 78 & 81 \\
\hline 17 & Artha Padan Audina Turnip & 71 & 73 & 70 & 82 \\
\hline 18 & Bastian Kevin Gultom & 76 & 82 & 83 & 82 \\
\hline 19 & Bela Tryangginy Manurung & 62 & 69 & 72 & 80 \\
\hline 20 & Bella Vista Tampubolon & 87 & 88 & 89 & 90
\end{tabular}

Data pada tabel 2.1 adalah data pelatihan yang akan dinormalisasi dengan sampel data sebanyak 20 (dua puluh) siswa dan training sampel mata pelajaran bahasa Indonesia.

Keterangan X1, X2, X3 dan Target:

$\mathrm{X} 1$ : Nilai Semester 1

X2 : Nilai Semester 2

X3 : Nilai Semester 3

Target : Nilai Semester 4

Untuk Data training yang sudah

dinormalisasi dapat dilihat pada tabel 2.2 berikut:

Tabel 2.2. Data Training di Normalisasi

\begin{tabular}{|c|l|c|c|c|c|}
\hline \multicolumn{5}{|c|}{ TRAINING } \\
\hline NO & \multicolumn{1}{|c|}{ Nama Siswa } & X1 & X2 & X3 & Target \\
\hline 1 & Ade Pramita Damanik & 0,90 & 0,62 & 0,75 & 0,75 \\
\hline 2 & Adlan Fadila & 0,42 & 0,51 & 0,40 & 0,66 \\
\hline 3 & Afriani Damanik & 0,19 & 0,45 & 0,81 & 0,73 \\
\hline 4 & Afry Wulan Sihaloho & 0,14 & 0,32 & 0,29 & 0,51 \\
\hline 5 & Agnes Marshinta Tambun & 0,60 & 0,66 & 0,64 & 0,66 \\
\hline 6 & Agung Martahan Sigiro & 0,14 & 0,36 & 0,34 & 0,51 \\
\hline 7 & Aisyah Fadhilah Nasution & 0,16 & 0,40 & 0,62 & 0,64 \\
\hline 8 & Andreas Natanael Purba & 0,10 & 0,29 & 0,27 & 0,34 \\
\hline 9 & Angga Antonius Silalahi & 0,14 & 0,32 & 0,42 & 0,49 \\
\hline 10 & Anggi Apriani & 0,58 & 0,81 & 0,84 & 0,86 \\
\hline 11 & Anggi Setiawan Simanjuntak & 0,12 & 0,36 & 0,29 & 0,62 \\
\hline 12 & Anggraini Darmayanti & 0,10 & 0,40 & 0,51 & 0,66 \\
\hline 13 & Anisa Putri Ardila & 0,51 & 0,73 & 0,66 & 0,66 \\
\hline 14 & Anugrah Debora Sibarani & 0,71 & 0,81 & 0,84 & 0,90 \\
\hline 15 & Aprilah Yuswani & 0,36 & 0,49 & 0,53 & 0,71 \\
\hline 16 & Armelita Kristianty Harahap & 0,49 & 0,58 & 0,58 & 0,64 \\
\hline 17 & Artha Padan Audina Turnip & 0,42 & 0,47 & 0,40 & 0,66 \\
\hline 18 & Bastian Kevin Gultom & 0,53 & 0,66 & 0,68 & 0,66 \\
\hline 19 & Bela Tryangginy Manurung & 0,23 & 0,38 & 0,45 & 0,62 \\
\hline 20 & Bella Vista Tampubolon & 0,77 & 0,79 & 0,81 & 0,84 \\
\hline
\end{tabular}


Pada tabel 2.2 menjelaskan bahwa data training yang sudah dinormalisasikan sampel data mata pelajaran bahasa Indonesia semester 1 sampai dengan semester 3 sedangkan sebagai target yakni semester 4. Dengan menggunakan fungsi sigmoid biner maka diperoleh data normalisasi dengan ketentuan, pada semester 1 sampai semester 4 diperoleh nilai Maksimum (b) sebesar 93 dan nilai Minimum (a) sebesar 56. Maksimum dan Minimum ditentukan berdasarkan dari semua data yang akan dilakukan pelatihan (data Training). Berikut ini adalah data testing sebelum dinormalisasi dapat dilihat pada tabel 2.3:

Tabel 2.3 Data Testing Sebelum dinormalisasi

\begin{tabular}{|c|c|c|c|c|c|}
\hline \multicolumn{6}{|c|}{ Testing } \\
\hline NO & Nama Siswa & $\mathrm{X} 1$ & $\mathrm{X} 2$ & $\mathrm{X} 3$ & Target \\
\hline 1 & Ade Pramita Damanik & 80 & 86 & 86 & 92 \\
\hline 2 & Adlan Fadila & 75 & 70 & 82 & 80 \\
\hline 3 & Afriani Damanik & 72 & 89 & 85 & 91 \\
\hline 4 & Afry Wulan Sihaloho & 66 & 65 & 75 & 80 \\
\hline 5 & Agnes Marshinta Tambun & 82 & 81 & 82 & 87 \\
\hline 6 & Agung Martahan Sigiro & 68 & 67 & 75 & 74 \\
\hline 7 & Aisyah Fadhilah Nasution & 70 & 80 & 81 & 86 \\
\hline 8 & Andreas Natanael Purba & 65 & 64 & 67 & 78 \\
\hline 9 & Angga Antonius Silalahi & 66 & 71 & 74 & 74 \\
\hline 10 & Anggi Apriani & 89 & 90 & 91 & 94 \\
\hline 11 & Anggi Setiawan Simanjuntak & 68 & 65 & 80 & 68 \\
\hline 12 & Anggraini Darmayanti & 70 & 75 & 82 & 78 \\
\hline 13 & Anisa Putri Ardila & 85 & 82 & 82 & 86 \\
\hline 14 & Anugrah Debora Sibarani & 89 & 90 & 93 & 93 \\
\hline 15 & Aprilah Yuswani & 74 & 76 & 84 & 86 \\
\hline 16 & Armelita Kristianty Harahap & 78 & 78 & 81 & 80 \\
\hline 17 & Artha Padan Audina Turnip & 73 & 70 & 82 & 81 \\
\hline 18 & Bastian Kevin Gultom & 82 & 83 & 82 & 89 \\
\hline 19 & Bela Tryangginy Manurung & 69 & 72 & 80 & 80 \\
\hline 20 & Bella Vista Tampubolon & 88 & 89 & 90 & 93 \\
\hline
\end{tabular}

Data pada tabel 2.3 diatas adalah data pengujian yang akan dinormalisasi dengan sampel data sebanyak 20 (dua puluh) siswa dan testing sampel mata pelajaran bahasa Indonesia.

Keterangan X1, X2, X3 dan Target :

$\mathrm{X} 1 \quad$ : Nilai Semester 2

$\mathrm{X} 2$ : Nilai Semester 3

X3 : Nilai Semester 4

Target : Nilai Semester 5

Untuk Data testing yang sudah dinormalisasi dapat dilihat pada tabel 2.4 berikut:
Tabel 2.4. Data Testing Yang di Normalisasi

\begin{tabular}{|c|c|c|c|c|c|}
\hline \multicolumn{6}{|c|}{ Testing } \\
\hline No & Nama Siswa & $\mathrm{X} 1$ & $\mathrm{X} 2$ & $\mathrm{X} 3$ & Target \\
\hline 1 & Ade Pramita Damanik & 0,53 & 0,69 & 0,69 & 0,85 \\
\hline 2 & Adlan Fadila & 0,39 & 0,26 & 0,58 & 0,53 \\
\hline 3 & Afriani Damanik & 0,31 & 0,77 & 0,66 & 0,82 \\
\hline 4 & Afry Wulan Sihaloho & 0,15 & 0,13 & 0,39 & 0,53 \\
\hline 5 & $\begin{array}{l}\text { Agnes Marshinta } \\
\text { Tambun }\end{array}$ & 0,58 & 0,55 & 0,58 & 0,71 \\
\hline 6 & $\begin{array}{l}\text { Agung Martahan } \\
\text { Sigiro }\end{array}$ & 0,21 & 0,18 & 0,39 & 0,37 \\
\hline 7 & $\begin{array}{l}\text { Aisyah Fadhilah } \\
\text { Nasution }\end{array}$ & 0,26 & 0,53 & 0,55 & 0,69 \\
\hline 8 & $\begin{array}{l}\text { Andreas Natanael } \\
\text { Purba }\end{array}$ & 0,13 & 0,10 & 0,18 & 0,47 \\
\hline 9 & $\begin{array}{l}\text { Angga Antonius } \\
\text { Silalahi }\end{array}$ & 0,15 & 0,29 & 0,37 & 0,37 \\
\hline 10 & Anggi Apriani & 0,77 & 0,79 & 0,82 & 0,90 \\
\hline 11 & $\begin{array}{l}\text { Anggi Setiawan } \\
\text { Simanjuntak } \\
\end{array}$ & 0,21 & 0,13 & 0,53 & 0,21 \\
\hline 12 & Anggraini Darmayanti & 0,26 & 0,39 & 0,58 & 0,47 \\
\hline 13 & Anisa Putri Ardila & 0,66 & 0,58 & 0,58 & 0,69 \\
\hline 14 & $\begin{array}{l}\text { Anugrah Debora } \\
\text { Sibarani }\end{array}$ & 0,77 & 0,79 & 0,87 & 0,87 \\
\hline 15 & Aprilah Yuswani & 0,37 & 0,42 & 0,63 & 0,69 \\
\hline 16 & $\begin{array}{l}\text { Armelita Kristianty } \\
\text { Harahap }\end{array}$ & 0,47 & 0,47 & 0,55 & 0,53 \\
\hline 17 & $\begin{array}{l}\text { Artha Padan Audina } \\
\text { Turnip }\end{array}$ & 0,34 & 0,26 & 0,58 & 0,55 \\
\hline 18 & Bastian Kevin Gultom & 0,58 & 0,61 & 0,58 & 0,77 \\
\hline 19 & $\begin{array}{l}\text { Bela Tryangginy } \\
\text { Manurung }\end{array}$ & 0,23 & 0,31 & 0,53 & 0,53 \\
\hline 20 & $\begin{array}{l}\text { Bella Vista } \\
\text { Tampubolon }\end{array}$ & 0,74 & 0,77 & 0,79 & 0,87 \\
\hline
\end{tabular}

Pada tabel 2.4 menjelaskan bahwa data testing yang sudah dinormalisasikan sampel data mata pelajaran bahasa Indonesia semester 2 sampai dengan semester 4 sedangkan sebagai target yakni semester 5. Dengan menggunakan fungsi sigmoid biner maka diperoleh data normalisasi dengan ketentuan, pada semester 2 sampai semester 5 diperoleh nilai Maksimum (b) sebesar 94 dan nilai Minimum (a) sebesar 64. Maksimum dan Minimum ditentukan berdasarkan dari semua data yang akan dilakukan pelatihan (data Testing).

\section{KESIMPULAN}

Pada sebuah penelitian diperlukan adanya kesimpulan dari pelatihan dan pengujian data yang dilakukan. Kesimpulan pada penelitian ini dapat dilihat sebagai berikut, tabel 3.1 :

\begin{tabular}{|c|c|c|c|c|c|c|}
\hline \multirow{2}{*}{ No } & \multirow{2}{*}{ Arsitektur } & \multicolumn{3}{|c|}{ Training } & \multicolumn{2}{c|}{ Testing } \\
\cline { 3 - 7 } & & Epoch & Waktu & MSE & MSE & Akurasi \\
\hline 1 & $3-12-1$ & 396 & $00: 02$ & 0,01005188 & 0,02683430 & $\mathbf{9 0 \%}$ \\
\hline 2 & $3-12-1$ & 33196 & $03: 06$ & 0,01006613 & 0,11514058 & $\mathbf{5 0 \%}$ \\
\hline 3 & $3-8-1$ & 461 & $00: 02$ & 0,03520619 & 0,11065593 & $\mathbf{5 5 \%}$ \\
\hline 4 & $3-16-1$ & 507 & $00: 02$ & 0,00985738 & 0,06791167 & $\mathbf{8 5 \%}$ \\
\hline
\end{tabular}

Baris keempat (4) yang bewarna kuning pada tabel 4.20 diatas adalah arsitektur terbaik 
dengan akurasi sebesar $90 \%$ pada mata pelajaran bahasa indonesia. Berikut penjelasan dari tabel 3.1 kesimpulan pelatihan dan pengujian jaringan syaraf tiruan:

Pada tahap ini akan dilakukan pengamatan terhadap laju pembelajaran kinerja jaringan dengan parameter tingkat akurasi, waktu pembelajaran, MSE selama proses pelatihan dan lamanya waktu iterasi (Epoch). Dengan memakai arsitektur jaringan terbaik pada pelatihan, maka akan diamati laju pembelajaran terhadap kinerja jaringan. Arsitektur yang digunakan untuk pelatihan sebanyak 5 arsitektur. Pada 5 arsitektur ini menggunakan Learning rate 0,1 target error (goal) 0,01 dan maksimum epoch nya adalah 100000 iterasi serta untuk menghasilkan error paling rendah menggunakan traingd.

Arsitektur pelatihan 3-12-1 menggunakan layer masukan sebanyak 3 neuron, layer tersembunyi sebanyak 12 neuron dan layer keluaran 1 neuron. Pelatihan 3-12-1 menghasilkan epoch sebesar 396 iterasi, waktu 00:02 , MSE pelatihan 0,01005188 dan MSE pengujian 0,02683430 dengan tingkat akurasi 90\%. Arsitektur pelatihan 3-12-1 menggunakan layer masukan sebanyak 3 neuron, layer tersembunyi sebanyak 12 neuron dan layer keluaran 1 neuron. Pelatihan 3-12-1 menghasilkan epoch sebesar 33196 iterasi, waktu 03:06 , MSE pelatihan 0,01006613 dan MSE pengujian 0,11514058 dengan tingkat akurasi 50\%. Arsitektur pelatihan 3-8-1 menggunakan layer masukan sebanyak 3 neuron, layer tersembunyi sebanyak 8 neuron dan layer keluaran 1 neuron. Pelatihan 3-8-1 menghasilkan epoch sebesar 461 iterasi, waktu 00:02, MSE pelatihan 0,03520619 dan MSE pengujian 0,11065593 dengan tingkat akurasi $55 \%$. Arsitektur pelatihan 3-16-1 menggunakan layer masukan sebanyak 3 neuron, layer tersembunyi sebanyak 16 neuron, dan layer keluaran sebanyak 1 neuron. Pelatihan 3-16-1 menghasilkan epoch sebesar 507 iterasi, waktu 00:02, MSE pelatihan 0,00985738 dan MSE pengujian 0,06791167 dengan tingkat akurasi $85 \%$.

\subsection{Prediksi Nilai Bahasa Indonesia Dengan} Arsitektur 3-12-1

Prediksi dilakukan dengan menggunakan arsitektur 3-12-1 dengan akurasi 90\%. Dengan layer masukan sebanyak 3 neuron, layer tersembunyi 12 neuron dan 1 neuron keluaran. Berikut proses prediksi pada tabel 3.2 :

Tabel 3.2. Prediksi Data Nilai Bahasa Indonesia

\begin{tabular}{|c|c|c|c|c|}
\hline No & Data Real & Target & Target Prediksi & Prediksi \\
\hline 1 & 92 & 0,85 & 0,80 & 90 \\
\hline 2 & 80 & 0,53 & 0,45 & 77 \\
\hline 3 & 91 & 0,82 & 0,74 & 88 \\
\hline 4 & 80 & 0,53 & 0,32 & 72 \\
\hline
\end{tabular}

\begin{tabular}{|l|l|l|l|l|}
5 & 87 & 0,71 & 0,72 & 87 \\
\hline 6 & 74 & 0,37 & 0,39 & 75 \\
\hline 7 & 86 & 0,69 & 0,69 & 86 \\
\hline 8 & 78 & 0,47 & 0,40 & 75 \\
\hline 9 & 74 & 0,37 & 0,60 & 83 \\
\hline 10 & 94 & 0,90 & 0,90 & 94 \\
\hline 11 & 68 & 0,21 & 0,42 & 76 \\
\hline 12 & 78 & 0,47 & 0,57 & 82 \\
\hline 13 & 86 & 0,69 & 0,72 & 87 \\
\hline 14 & 93 & 0,87 & 0,90 & 94 \\
\hline 15 & 86 & 0,69 & 0,60 & 83 \\
\hline 16 & 80 & 0,53 & 0,63 & 84 \\
\hline 17 & 81 & 0,55 & 0,50 & 79 \\
\hline 18 & 89 & 0,77 & 0,73 & 88 \\
\hline 19 & 80 & 0,53 & 0,50 & 79 \\
\hline 20 & 93 & 0,87 & 0,90 & 94 \\
\hline
\end{tabular}

Data real adalah data yang diperoleh dari data semester akhir. Data target diperoleh dari data Testing yang sudah di normalisasi. Target estimasi pada tabel diperoleh dari hasil pengujian menggunakan software Matlab R2011b, Adapun rumus yang digunakan untuk menetapkan pengujian dengan parameter pada pelatihan ini, dijabarkan sebagai berikut:

$>$

net $=$ newff(minmax $(P P),[12,1] .\{$ 'logsig', 'tansig'\}, 'tr aingd');

$>$ net $=I W\{1,1\}$;

$>$ net.b $\{1\}$;

$>$ net. $L W\{2,1\}$;

$>$ net.b $\{2\}$;

$>>$ net.trainParam.epochs $=100000$;

$>$ net.trainParam.goal $=0,001$;

$>$ net.trainParam. $L r=0.01$;

$>$ net.trainParam. show $=1000$;

$>$ net $=\operatorname{train}($ net $, P P, T T)$

$[a, P f, A f, e, P e r f]=\operatorname{sim}($ net $, P P,[],[], T T)$

Prediksi $=\frac{(\text { output }-a .1)(b-a)}{0.8}+a$

\subsection{Prediksi Nilai Bahasa Inggris Dengan Arsitektur 3-12-1}

Prediksi dilakukan dengan menggunakan arsitektur 3-12-1 dengan akurasi 50\%. Dengan layer masukan sebanyak 3 neuron, layer tersembunyi 12 neuron dan 1 neuron keluaran. Berikut proses prediksi pada tabel 3.3: 
JUSIKOM PRIMA (Jurnal Sistem Informasi dan Ilmu Komputer Prima)

Vol. 4 No. 2, Februari 2021

E-ISSN : 2580-2879

Tabel 3.3. Prediksi Bahasa Inggris

\begin{tabular}{|c|c|c|c|c|}
\hline No & Data Real & Target & Target Prediksi & Prediksi \\
\hline 1 & 92 & 0,85 & 0,84 & 89 \\
\hline 2 & 72 & 0,53 & 0,42 & 69 \\
\hline 3 & 73 & 0,82 & 0,57 & 76 \\
\hline 4 & 72 & 0,53 & 0,73 & 84 \\
\hline 5 & 77 & 0,71 & 0,61 & 78 \\
\hline 6 & 72 & 0,37 & 0,68 & 82 \\
\hline 7 & 77 & 0,69 & 0,60 & 78 \\
\hline 8 & 72 & 0,47 & 0,43 & 70 \\
\hline 9 & 81 & 0,37 & 0,62 & 79 \\
\hline 10 & 76 & 0,90 & 0,56 & 76 \\
\hline 11 & 70 & 0,21 & 0,49 & 72 \\
\hline 12 & 70 & 0,47 & 0,52 & 74 \\
\hline 13 & 79 & 0,69 & 0,48 & 72 \\
\hline 14 & 78 & 0,87 & 0,75 & 85 \\
\hline 15 & 77 & 0,69 & 0,48 & 72 \\
\hline 16 & 74 & 0,53 & 0,48 & 72 \\
\hline 17 & 73 & 0,55 & 0,40 & 68 \\
\hline 18 & 72 & 0,77 & 0,44 & 70 \\
\hline 19 & 82 & 0,53 & 0,67 & 81 \\
\hline 20 & 84 & 0,87 & 0,75 & 85 \\
\hline
\end{tabular}

Data real adalah data yang diperoleh dari data semester akhir. Data target diperoleh dari data Testing yang sudah di normalisasi. Target estimasi pada tabel diperoleh dari hasil pengujian menggunakan software Matlab R2011b, Adapun rumus yang digunakan untuk menetapkan pengujian dengan parameter pada pelatihan ini, dijabarkan sebagai berikut:

$>>$

net=newff(minmax (PP),[12,1].\{'logsig', 'tansig'\}, 'tr aingd');

$>$ net $=I W\{1,1\}$;

$>$ net.b $\{1\}$

$>$ net. $L W\{2,1\}$;

$>$ net.b $\{2\}$;

$>>$ net.trainParam.epochs $=100000$;

$>$ net.trainParam.goal $=0,01$;

$>$ net.trainParam. $L r=0.1$;

$>$ net.trainParam.show $=1000$;

$>$ net $=\operatorname{train}($ net $, P P, T T)$

[a,Pf,Af,e,Perf] =sim(net,PP,[],[],TT)

3.3 Prediksi Nilai ujian nasional Dengan

Arsitektur 3-8-1

Prediksi dilakukan dengan menggunakan arsitektur 3-8-1 dengan akurasi 55\%. Dengan layer masukan sebanyak 3 neuron, layer tersembunyi 8 neuron dan 1 neuron keluaran. Berikut proses prediksi pada tabel 3.4 :

Tabel 3.4. Prediksi Data Nilai

\begin{tabular}{|c|c|c|c|c|}
\hline No & Data Real & Target & Target Prediksi & Prediksi \\
\hline 1 & 81 & 0,73 & 0,96 & 89 \\
\hline 2 & 80 & 0,73 & 0,96 & 89 \\
\hline 3 & 78 & 0,71 & 0,67 & 79 \\
\hline 4 & 77 & 0,65 & 0,62 & 77 \\
\hline 5 & 78 & 0,62 & 0,76 & 82 \\
\hline 6 & 78 & 0,65 & 0,61 & 77 \\
\hline 7 & 78 & 0,65 & 0,68 & 79 \\
\hline 8 & 76 & 0,65 & 0,62 & 77 \\
\hline 9 & 78 & 0,60 & 0,63 & 77 \\
\hline 10 & 78 & 0,65 & 0,63 & 77 \\
\hline 11 & 77 & 0,65 & 0,67 & 79 \\
\hline 12 & 78 & 0,62 & 0,62 & 77 \\
\hline 13 & 77 & 0,65 & 0,62 & 77 \\
\hline 14 & 87 & 0,62 & 0,56 & 75 \\
\hline 15 & 78 & 0,90 & 0,70 & 80 \\
\hline 16 & 78 & 0,65 & 0,69 & 80 \\
\hline 17 & 77 & 0,65 & 0,63 & 77 \\
\hline 18 & 77 & 0,62 & 0,63 & 77 \\
\hline 19 & 78 & 0,62 & 0,64 & 78 \\
\hline 20 & 82 & 0,65 & 0,79 & 83 \\
\hline
\end{tabular}

Data real adalah data yang diperoleh dari data semester akhir. Data target diperoleh dari data Testing yang sudah di normalisasi. Target estimasi pada tabel diperoleh dari hasil pengujian menggunakan software Matlab R2011b, Adapun rumus yang digunakan untuk menetapkan pengujian dengan parameter pada pelatihan ini, dijabarkan sebagai berikut:

$>$

net=newff(minmax (PP), [8,1].\{'logsig', 'tansig'\}, 'tra ingd');

$>$ net $=I W\{1,1\}$;

$>$ net.b $\{1\}$;

$>$ net. $L W\{2,1\}$;

$>$ net.b $\{2\}$;

$>>$ net.trainParam.epochs $=100000$;

$>$ net.trainParam.goal $=0,01$;

$>>$ net.trainParam. $L r=0.1$;

$>$ net.trainParam. show $=1000$;

$>$ net $=\operatorname{train}($ net, $P P, T T)$

[a,Pf,Af,e,Perf] =sim(net,PP,[],[],TT)

3.4 Prediksi Nilai Biologi Dengan Arsitektur 3 16-1

Prediksi dilakukan dengan menggunakan arsitektur 3-16-1 dengan akurasi 85\%. Dengan layer 
masukan sebanyak 3 neuron, layer tersembunyi 16 neuron dan 1 neuron keluaran. Berikut proses prediksi pada tabel 3.5:

Tabel 3.5. Prediksi Data Nilai

\begin{tabular}{|c|c|c|c|c|}
\hline No & Data Real & Target & $\begin{array}{c}\text { Target } \\
\text { Prediksi }\end{array}$ & Prediksi \\
\hline 1 & 79 & 0,67 & 0,76 & 83 \\
\hline 2 & 63 & 0,25 & 0,34 & 66 \\
\hline 3 & 67 & 0,36 & 0,40 & 69 \\
\hline 4 & 65 & 0,31 & 0,42 & 69 \\
\hline 5 & 72 & 0,49 & 0,33 & 66 \\
\hline 6 & 66 & 0,33 & 0,28 & 64 \\
\hline 7 & 67 & 0,36 & 0,29 & 64 \\
\hline 8 & 61 & 0,20 & 0,30 & 65 \\
\hline 9 & 66 & 0,33 & 0,33 & 66 \\
\hline 10 & 81 & 0,72 & 0,77 & 83 \\
\hline 11 & 65 & 0,31 & 0,22 & 62 \\
\hline 12 & 66 & 0,33 & 0,35 & 66 \\
\hline 13 & 69 & 0,41 & 0,29 & 64 \\
\hline 14 & 77 & 0,62 & 0,88 & 87 \\
\hline 15 & 78 & 0,64 & 0,64 & 78 \\
\hline 16 & 68 & 0,38 & 0,30 & 65 \\
\hline 17 & 67 & 0,36 & 0,33 & 66 \\
\hline 18 & 68 & 0,38 & 0,54 & 74 \\
\hline 19 & 68 & 0,38 & 0,44 & 70 \\
\hline 20 & 88 & 0,90 & 0,84 & 86 \\
\hline
\end{tabular}

Data real adalah data yang diperoleh dari data semester akhir. Data target diperoleh dari data Testing yang sudah di normalisasi. Target estimasi pada tabel diperoleh dari hasil pengujian menggunakan software Matlab R2011b, Adapun rumus yang digunakan untuk menetapkan pengujian dengan parameter pada pelatihan ini, dijabarkan sebagai berikut:

$>>$

net=newff(minmax (PP),[12,1]. \{'logsig', 'tansig'\}, 'tr aingd');

$>$ net $=I W\{1,1\}$;

$>$ net.b $\{1\}$;

$>$ net. $L W\{2,1\}$;

$>$ net.b $\{2\}$;

$>$ net.trainParam.epochs $=100000$;

$>$ net.trainParam.goal $=0,001$;

$>$ net.trainParam. Lr $=0.01$;

$>$ net.trainParam. show $=1000$;

$>$ net $=\operatorname{train}($ net $, P P, T T)$

$[a, P f, A f, e, P e r f]=\operatorname{sim}($ net $, P P,[],[], T T)$

Prediksi $=\frac{(\text { output }-0.1)(b-a)}{0.8}+a$

\section{PENUTUP}

Pelaksanaan penelitian menggunakan jaringan syaraf tiruan dengan algoritma backpropagation menghasilkan prediksi yang cukup baik dan pemrosesan data yang cepat. Dalam penelitian telah dilakukan perancangan, proses pembuatan, implementasi sampai evaluasi sehingga ditetapkan kesimpulan sebagai berikut:

1) Dalam memprediksi jaringan syaraf tiruan mampu menghasilkan akurasi yang cukup akurat pada hasil pengolahan data testing.

2) Learning Rate sangat mempengaruhi kecepatan hasil iterasi maupun tingkat akurasi yang dihasilkan.

Penelitian ini menghasilkan arsitektur terbaik yakni 3-12-1 pada pengolahan data nilai bahasa Indonesia dengan tingkat akurasi $95 \%$.

Untuk penelitian selanjutnya perlu adanya percepatan dan optimasi dalam melakukan proses prediksi serta pengaplikasian algoritma backpropagation dengan algoritma jaringan syaraf tiruan lain agar menghasilkan optimasi yang lebih baik dan stabil.

\section{DAFTAR PUSTAKA}

[1] Lesnussa, Y. A., Latuconsina, S., \& Persulessy, E. R. (2015). Aplikasi Jaringan Saraf Tiruan Backpropagation untuk Memprediksi Prestasi Siswa SMA ( Studi kasus: Prediksi Prestasi Siswa SMAN 4 Ambon ). Jurnal Matematika Integratif, 11(2), 149-160.

[2] Nafi'iyah, N. (2020). Analisis Algoritma Backpropagation Dengan SVM Dalam Hasil Prediksi Nilai Ujian Nasional Pada Sekolah Tingkat Pertama. Jurnal Informatika, Manajemen Dan Komputer, 12(1), 5-13.

[3] Aji, D. K. P., \& Khotimah, N. (2014). Prediksi Diskalkulia Menggunakan Jaringan Syaraf Tiruan Backpropagation. Jurnal SPIRIT, 6(1), 1-10.

[4] Budiharto, W., \& Suhartono, D. (2014). ARTIFICIAL INTELLIGENCE KONSEP DAN PENERAPANNYA (Seno (ed.); Ed. I). C.V ANDI OFFSET.

[5] Hasan, N. F., Kusrini, \& Fatta, H. Al. (2019). Peramalan Jumlah Penjualan Menggunakan Jaringan Syaraf Tiruan Backpropagation Pada Perusahaan Air Minum Dalam Kemasan. Jurnal Teknik Informatika Dan Sistem Informasi, $\quad 5(2), \quad$ 179-188. https://doi.org/http://dx.doi.org/10.28932/jutisi .v5i2.1607

[6] Hendini, A. (2016). Pemodelan UML sistem 
informasi Monitoring Penjualan dan stok barang. Jurnal Khatulistia Informatika, IV(2), 107-116.

[7] Kusumaningtyas, S., \& Asmara, R. A. (2016). Identifikasi Kematangan Buah Tomat Berdasarkan Warna Menggunakan Metode Jaringan Syaraf Tiruan (JST). Jurnal Informatika Polinema, 2(2), 72-75.

[8] Lestari, Y. D. (2017). Jaringan Syaraf Tiruan Untuk Prediksi Penjualan Jamur Menggunakan Algoritma Backropagation. Journal Information System Development (ISD), 2(1), 40-46.

[9] M.Fowler. (2017). UNIFIED MODELING $L A N G U A G E$.

[10] Mcnelis, P. D. (2005). Neural Networks in Finance Gaining Predictive Edge In The Market. Elsevier Academic Press.

[11] Novita, A. (2016). Prediksi Pergerakan Harga Saham Pada Bank Terbesar Di Indonesia Dengan Metode Backpropagation Neural Network. Jutisi, 5(1), 965-972.

[12] Nuraeni, Y. (2009). Penerapan Jaringan Syaraf Tiruan Untuk Mengukur Tingkat Korelasi Antara Nem Dengan Ipk Kelulusan Mahasiswa. TELKOMNIKA (Telecommunication Computing Electronics and Control), 7(3), 195. https://doi.org/10.12928/telkomnika.v7i3.594

[13] Ostad-ali-askari, K., Shayannejad, M., \& Ghorbanizadeh-kharazi, H. (2017). Artificial Neural Network for Modeling Nitrate Pollution of Groundwater in Marginal Area of Zayandeh-rood River, Isfahan, Iran. KSCE Journal of Civil Engineering, 21, 134-135. https://doi.org/10.1007/s12205-016-0572-8

[14] Santoso, \& Yuliyanti, W. (2016). Perencanaan Dan Pembuatan Aplikasi Absensi Dosen Menggunakan Radio Frequency Identification ( RFID ) ( Studi Kasus Politeknik Negeri Tanah Laut ). SEMINAR NASIONAL INOVASI DAN APLIKASI TEKNOLOGI DI INDUSTRI (SENIATI), 332-337.

[15] Siregar, S. P., Wanto, A., \& Nasution, Z. M. (2018). Analisis Akurasi Arsitektur JST Berdasarkan Jumlah Penduduk Pada Kabupaten / Kota di Sumatera Utara. Seminar Nasional Sains \& Teknologi Informasi (SENSASI), 526-536.

[16] Tan, M., Li, J., Xu, G., \& Cheng, X. (2019). A Novel Intuitionistic Fuzzy Inhibitor Arc Petri Net With Error Back Propagation Algorithm and Application in Fault Diagnosis. IEEE Access, 7, 115978-115988. https://doi.org/10.1109/ACCESS.2019.293621 2

[17] Taufik, I., \& Sitio, A. S. (2018). Implementasi Jaringan Syaraf Tiruan Untuk Pengelompokkan Minat Kompetensi Mahasiswa STMIK Pelita Nusantara Medan.
Jurnal Mantik Penusa, 2(2), 80-83.

[18] Utari, W. A. (2018). Pengenalan pola dengan menggunakan metode backpropagation menggunakan matlab.

[19] Walker, E. G., \& David. (2020). Application of Backpropagation Artificial Neural Networks in the TORCH Virus Diagnosis Expert System. Jurnal Ilmiah SISFOTENIKA, 10(1), 87-102.

[20] Wiyanti, D. T., Negeri, U., \& Unnes, S. (2018). Analisis Produktivitas Kinerja Dosen dan Tenaga Kependidikan dalam Mewujudkan Tahun Reputasi Universitas Negeri Semarang ( UNNES ) Menggunakan Jaringan Saraf Tiruan. 1, 919-927.

Contac person Author: $\quad$ RANI Hp : 081397155571 